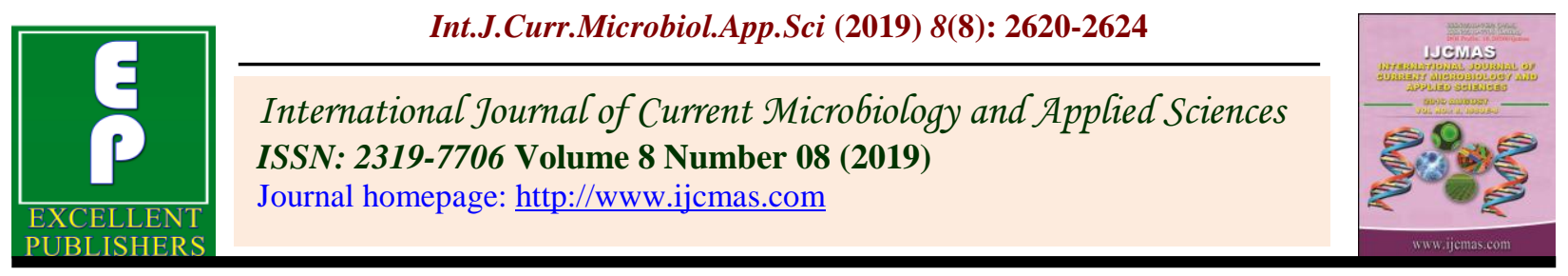

Original Research Article

https://doi.org/10.20546/ijcmas.2019.808.304

\title{
Percent Yield of Ovine Mesenchymal Stem Cells (ADMSCs) from Different Sources of Adipose Tissue
}

\author{
R. Gnanadevi ${ }^{1}$, T. A. Kannan ${ }^{1 *}$, Geetha Ramesh ${ }^{1}$ and Sabiha Hayath Basha ${ }^{2}$ \\ ${ }^{1}$ Department of Veterinary Anatomy, Madras Veterinary College, Tamil Nadu Veterinary and \\ Animal Sciences University, India \\ ${ }^{2}$ Center for Stem cell Research and Regenerative Medicine, Madras Veterinary College, Tamil \\ Nadu Veterinary and Animal Sciences University, India \\ *Corresponding author
}

\section{A B S T R A C T}

Adipose derived mesenchymal stem cells are gaining importance due to its wide distribution and ability to differentiate into tissues of mesenchymal

Keywords

Percent yield, ADMSCs, Stem cell, Sheep

Article Info

Accepted:

22 July 2019

Available Online:

10 August 2019 origin viz., bone, cartilage, muscle and adipocytes. In the present study, adipose tissue samples from subcutaneous, omental, renal and perineal fat where collected and ADMSCs were isolated using 0.075 percent of collagenase type I. Cell viability was determined by trypan blue exclusion test and the viable cells were counted and cell yield was calculated. In this study, cell yield was found to be highest in renal fat $(10.50 \pm 0.22$ million per $\mathrm{ml})$ and lowest in scrotal fat $(0.75 \pm 0.09$ million per $\mathrm{ml})$. Subcutaneous fat yielded $2.12 \pm 0.19$ million per ml, perineal fat $2.23 \pm 0.08$ million per $\mathrm{ml}$ and omental fat $1.59 \pm 0.18$ million per ml. Though yield of ADMSCs was the maximum in renal fat, due to the easy and non-invasive collection procedure and equally high level of viability, subcutaneous fat was considered as the choice of tissue collection site for further studies in sheep.

\section{Introduction}

Stem cells exist in an undifferentiated state and exhibit both the capacity to self-renew and the capability to differentiate into more than one type of cell. Although embryonic stem cells seem to exhibit unlimited differentiation potential both in-vitro and in-vivo, they are subject to significant ethical, legal and political concerns and are not generally available in current medical practice or research (Locke et al., 2009).

Veterinary applications of stem cell therapy as a mean of tissue regeneration have been largely shaped by research that began with the use of adult-derived mesenchymal stem cells to treat animals with injuries or defects affecting bone, cartilage, ligaments and/or tendons (Bruder et al., 1998). 
Repair of major fractures, better outcomes of major reconstruction surgeries, and implants such as hip replacement are of equal concern in both human and veterinary medicine.

One major area of great potential is the use of mesenchymal stem cells (MSCs) for the restoration of bone defects. Adipose tissue is an attractive source of MSCs because of its abundance and easy access with minimal donor site morbidity (Neupane et al., 2008).

In human, adipose tissue can be harvested in large amounts with minimal morbidity. It contains numerous cells types, including adipocytes, preadipocytes, vascular endothelial cells and vascular smooth muscle cells; it also contains stem cells that have the ability to differentiate into several lineages, such as fat, bone, cartilage, muscle etc (Fraser et al., 2006).

Adipose tissue has been proven to serve as an abundant, accessible and rich source of adult stem cells with multipotent property which leads to its usage in tissue engineering and regenerative medical applications (Bunnel et al., 2008).

Temperament of sheep and their similar size to human has led to them being commonly used as surgical models. Sheep has been used as a model for bone repair and for the treatment of large segmental bone defects using tissue engineering (Jean-Pierre et al., 2008).

Due to the wide distribution of adipose tissue there are different source for the collection of adipose tissue viz., subcutaneous, omental and inguinal fat (Neupane et al., 2008).

The present study aimed to compare the percent yield of ADMSCs from different sources viz., subcutaneous, omental, renal, perineal and scrotal fat in ovine.

\section{Materials and Methods}

Adipose tissue samples of different sources viz., subcutaneous, omental, renal, perineal and scrotal fat were collected from adult sheep irrespective of sex and breed from Chennai Corporation slaughter house, Perambur. Number of samples of adipose tissue collected from different regions was given in table (Table 1) as per the need of culture work.

\section{Collection of Ovine Adipose Tissue}

Collected adipose tissue samples were put in a sample collection bottle contained of normal saline with antibiotic, antimycotic and povidone-Iodine solution. Then, they were kept in room temperature and processed within 1 hour. Adipose tissue of $2 \mathrm{~g}$ were weighed by using an electronic weighing balance and washed 3 to 4 times with equal volume of normal saline containing antibiotic, antimycotic solution (Vieira et al., 2010). Storage of tissue samples at $4^{\circ} \mathrm{C}$ was avoided because it reduced the activity of digestive enzyme (Beaulah et al., 2016).

\section{Isolation of Ovine ADMSCs}

The weighed tissue samples were teased into small bits of about 3 to $5 \mathrm{~mm}$ in size by use of sterile scissors, forceps and surgical blade.

Tissue samples were digested with 0.075 per cent collagenase type I (SIGMA®) for about 15 minutes and transferred to a beaker with magnetic stirrer and kept in stirrer with 100 $\mathrm{rpm}$ at $37^{\circ} \mathrm{C}$ for about one hour (Guercio et al., 2012).

After digestion, two phases were formed namely upper and lower phases. Upper phase contained floating digested adipose tissue and the lower phase contained mesenchymal stem cells, erythrocytes and leukocytes. Lower phase contained stromal vascular fraction was 
pipetted out and $2 \mathrm{ml}$ of Dulbecco's modified Eagle's medium-high glucose (DMEM-HG) with fetal bovine serum (FBS) and antibiotic solution (45 ml DMEM-HG, $5 \mathrm{ml}$ of 10 per cent FBS, $0.5 \mathrm{ml}$ of antibiotic solution) was added to it.

Finally, it was centrifuged at $2500 \mathrm{rpm}$ for 10 minutes as recovery of adipose stem cells could be improved by manipulating the centrifugation speed to pellet the cells (Bunnel et al., 2008).

Supernatant was discarded and the cell pellet was resuspended with $1 \mathrm{ml}$ of DMEM-HG with 10 per cent FBS to get cell suspension.

\section{Viability of the cell}

Cell viability and total cell density were demonstrated by Trypan blue exclusion test. Equal volumes of cell suspension $(10 \mu \mathrm{l})$ and Trypan blue ( 0.4 per cent) were added to see the viability of cells. The viable cells with transparent cytoplasm were counted manually in haemocytometer (Neubauer's chamber) (Jain et al., 2018).

\section{Formula Used}

Cell yield $=($ Total number of cells $\times$ dilution factor) $/ 10^{-4}$

\section{Statistical Analysis}

Mean and standard error were calculated for cell yield as per standard protocol mentioned in Snedecor and Cochran, (1994).

\section{Results and Discussion}

\section{Cell viability and Cell yield}

Cell viability and density were determined after isolation of ADMSCs. Viability of cells was confirmed by the transparent cytoplasm in the trypan blue exclusion test. But, the cytoplasm of dead cells was appeared to be stained with trypan blue. Cell density or cell yield was calculated by using Neubauer's chamber.

Cell yield (in millions) per $\mathrm{ml}$ of cell suspension and cell viability from different sources after enzymatic digestion were given in Table 2

In the present study, cell yield was found to be highest in renal fat $(10.50 \pm 0.22)$ and lowest in scrotal fat $(0.75 \pm 0.09)$. Subcutaneous fat of adult sheep yielded more adipose tissue derived mesenchymal stem cells $(2.12 \pm 0.19$ million per $\mathrm{ml}$ ) than that of omental fat (1.59 \pm 0.18 million per $\mathrm{ml})$. This is in contrast to the findings of Hepshiba et al., (2011) who reported that subcutaneous fat yielded $0.5 \times 10^{6}$ cells and omental fat yielded $0.38 \times 10^{6}$ cells in buffalo. Neupane et al., (2008) reported that ADMSCs from the subcutaneous fat in canine yielded $0.52 \pm 0.23 \times 10^{6}$ cells.

Though yield of ADMSCs was found to be maximum in renal fat, collection of adipose tissue from live animal will involve anesthesia, surgical procedure and postoperative healing etc, whereas collection of subcutaneous adipose tissue requires a minimal and non-invasive technique. Though variations found with regard to yield of ADMSCs from different sources of adipose tissue, cell viability was more than $90 \%$ in all the different sources except perineal fat (85$90 \%$ ).

Adult Mesenchymal stem cells could be derived from various sources, but adipose tissue was the most abundant source of adult MSCs in sheep. Based on the results, it is concluded that subcutaneous fat yields sufficient population of ADMSCs. Also collection procedure involves less morbidity to the animal. 
Table.1 Source and number of adipose tissue samples

\begin{tabular}{|c|c|c|}
\hline Sl. no & Sources of sample & $\begin{array}{c}\text { Number of samples } \\
\text { collected }\end{array}$ \\
\hline $\mathbf{1}$ & Subcutaneous fat & 25 \\
\hline $\mathbf{2}$ & Omental fat & 23 \\
\hline $\mathbf{3}$ & Renal fat & 26 \\
\hline $\mathbf{4}$ & Perineal fat & 22 \\
\hline $\mathbf{5}$ & Scrotal fat & 25 \\
\hline
\end{tabular}

Table.2 Cell yield (in millions) per $\mathrm{ml}$ of cell suspension from different sources

\begin{tabular}{|c|c|c|c|}
\hline $\begin{array}{c}\text { Source of sample } \\
(\mathbf{n = 6})\end{array}$ & $\begin{array}{c}\text { Weight of the } \\
\text { sample in } \\
\text { grams }\end{array}$ & $\begin{array}{c}\text { Yield in millions } \\
\text { (Mean } \pm \text { SE) }\end{array}$ & $\begin{array}{c}\text { Cell } \\
\text { viability } \\
(\boldsymbol{\%})\end{array}$ \\
\hline Subcutaneous fat & 2 & $2.12 \pm 0.19$ & $>90$ \\
\hline Omental fat & 2 & $1.59 \pm 0.18$ & $>90$ \\
\hline Renal fat & 2 & $10.50 \pm 0.22$ & $>90$ \\
\hline Scrotal fat & 2 & $0.75 \pm 0.09$ & $>90$ \\
\hline Perineal fat & 2 & $2.23 \pm 0.08$ & $85-90$ \\
\hline
\end{tabular}

Hence, in sheep, subcutaneous fat will be an ideal source for ADMSCs to be used in cell based therapy. The study also pave way for future research involves difference if any in propagation and differentiation capacity among these different sources of adipose tissue and also karyotype studies between subsequent passages.

\section{Acknowledgement}

The authors acknowledge the Dean, Madras Veterinary College for providing necessary support to carry out this project.

\section{References}

Beaulah, J.V., Ushakumary, S., Kannan, T.A., Justin William, B., Geetha Ramesh, Parthiban, M. and Raja, A. 2016(a). Culture and expansion of Adipose derived Mesenchymal stem cells in Ovine. Indian J. Anim. Res., DOI: 10.18805/ijar.v0iOF.7001.
Bruder, S.P., Kraus, K.H., Goldberg, V.M. and Kadiyala, S. 1998. The effect of implants loaded with autologous mesenchymal stem cells on the healing of canine segmental bone defects. J. Bone Joint Surg. Am., 80(7):985-96.

Bunnel, B. A., Flaat, M., Gagliardi, C., Patel, B. and Ripoll, C. 2008.Adipose-derived stem Cells: Isolation, Expansion and Differentiation. NIH Public Access Author Manuscript, 45(2): 115-120.

Fraser, K. J., I. Wulur, Z. Alfonso and Hedrick, M. H. 2006. Fat tissue: an underappreciated source of stem cells for biotechnology. Trends in Biotechnology, 24 (4): 150-154.

Guercio, A., Marco, A. D., Casella, S., Cannella, V., Russotto, L., Purpari, G., Bella, S. D. and Piccione, G. 2012. Production of canine mesenchymal stem cells from adipose tissue and their application in dogs with chronic osteoarthritis of the humeroradial joints.Cell Biol. Int., 36: 189-194. 
Hepsibha, P., Meenambigai, T. V., Mangalagowri, A., Palanisamy, A., Stalin, A., Nithya S. and Kumanan, K. 2011. Multipotent Differentiation potential of Buffalo Adipose tissue derived Mesenchymal stem cells. Asian J.Anim.Vet.Adv., 6(8): 772-788.

Jain, S. K., Jain, H., Sarkhel, B. C. and Pandey, A. K. 2018. Single cell proliferation to produce monoclonal population of transfected caprine fibroblast cell. IJAEB., 11(5): 719-724.

Jean-Pierre Y. Scheerlinck, Kenneth J. Snibson, Vernon M. Bowles and Philip Sutton. 2008. Biomedical applications of sheep models: from asthma to vaccines. Trends in Biotechnology, 26(5): 259-266.
Locke, M., Windsort, J. and Dunbar, P. R. 2009. Human adipose-derived stem cells: isolation characterization and applications in surgery. ANZ J. Surg., 79: 235-244.

Neupane, M., Chang, C. C., Kiupe, M. and Burkan, V. Y. 2008. Isolation and characterization of canine adiposeerived mesenchymal stem cells. Tissue Engineering, 14 (6): 1007 -1015.

Snedecor, C.W. and Cochran, W.G.1994. Statistical methods. $9^{\text {th }}$ Edn., Iowa state University press, Ames, Iowa.

Vieira, N. M., Brandalise, V., Zucconi, E., Secco, M., Strauss, B. E. and Zatz, M. 2010. Isolation, characterization, and differentiation potential of canine adipose-derived stem cells. Cell Transplantation. 19: 279-289.

\section{How to cite this article:}

Gnanadevi R., T. A. Kannan, Geetha Ramesh and Sabiha Hayath Basha. 2019. Percent Yield of Ovine Mesenchymal Stem Cells (ADMSCs) from Different Sources of Adipose Tissue. Int.J.Curr.Microbiol.App.Sci. 8(08): 2620-2624. doi: https://doi.org/10.20546/ijcmas.2019.808.304 